\title{
Madin-Darby Canine Kidney Cells Display Type I and Type II Insulin-like Growth Factor (IGF) Receptors
}

\author{
Nancy L. Krett, Joanne H. Heaton and Thomas D. Gelehrter
}

Departments of Human Genetics and Internal Medicine

University of Michigan Medical School, Ann Arbor, MI 48109

Received November 18, 1985

Using affinity cross-linking techniques, we report the presence of type I IGF and type II IGF receptors in Madin-Darby canine kidney cells, a line of cells lacking insulin receptors. The IGF receptors were further characterized by competition binding studies and found to be similar to IGF receptors in other tissue types. In Madin-Darby canine kidney cells, the type I IGF receptor binds IGF-I > IGF-II > insulin and the type II IGF receptor binds IGF-II and IGF-I with approximately the same affinity, but does not bind insulin. (9) 1986 Academic Press, Inc.

Madin-Darby canine kidney $(\mathrm{MDCK})^{1}$ cells are an established line of epithelial cells that have been reported to lack plasma membrane insulin binding sites and yet display insulinomimetic responses to concanavalin $A$, wheat germ agglutinin and hydrogen peroxide $(1,2)$. Thus, MDCK cells are an interesting system to use in studying insulin-like actions in the absence of the insulin receptor. Insulin-like growth factors (IGFs) are a family of polypeptides that stimulate many of the same responses as insulin $(3,4)$. Although the IGFs interact weakly with the insulin receptor, two distinct receptors for IGFs have been described (3). Due to the cross-reactivity of the

${ }^{1}$ Abbreviations used: MDCK, Madin-Darby canine kidney; IGF, insulin-like growth factor; SDS, sodium dodecyl sulfate. 
IGFs and insulin for the heterologous receptors, it is difficult to distinguish which receptor mediates a particular response. MDCK cells may offer the opportunity to study IGF actions in the absence of an insulin receptor. In this report, we describe both type I IGF and type II IGF receptors in MDCK cells on the basis of affinity cross-linking studies and competition binding studies.

\section{MATERIALS AND METHODS}

CELLS: MDCK cells were provided by Dr. Cecilia Hofmann, Hines VA Hospital, Maywood, IL. and H-35 cells were provided by Dr. John Koontz of the University of Tennessee, Knoxville, TN. Cells were grown in monolayer culture in antibiotic-free alpha-MEM (GIBCO) supplemented with $2.2 \mathrm{mg} / \mathrm{ml}$ sodium bicarbonate, $5 \%$ fetal bovine serum, $5 \%$ calf serum and $2 \mathrm{mM}$ glutamine.

MATERIALS; Crystaline porcine insulin was a gift of Dr. R.E. Chance, Lilly Reasearch Laboratories. Preparations of human IGF-I (preparation I/4) and IGF-II (preparation 9 SE IV) as well as a partially purified mixture, (preparation IGF 1932), were kindly provided by Dr. Rene Humbel, Biochemistry Institute, University of Zürich, Switzerland. IGF-I and IGF-II were labeled with $125_{\text {I to a }}$ specific activity of 200 and $168 \mathrm{mCi} / \mathrm{mg}$ respectiviely, by the Iodogen method (5). Iodogen was purchased from Pierce Chemical Co. 125 l-labeled insulin $(110 \mathrm{Ci} / \mathrm{g})$ was purchased from New England Nuclear. Trasylol and filamin were purchased from Calbiochem-Berhring and molecular weight standards were purchased from Biorad Laboratories.

HQRMONE BINDING ASSAY: Because serum contains IGF binding proteins which may interfere with the binding of IGF to its receptor (6), cells were first incubated in serum-free Eagles MEM containing $0.1 \%$ bovine serum albumin, $2 \mathrm{mM} \mathrm{CaCl}{ }_{2}, 50 \mu \mathrm{g} / \mathrm{ml}$ neomycin and $2 \mathrm{mM}$ glutamine for eighteen hours. Confluent monolayers of MDCK cells were washed twice with phosphate buffered saline, $\mathrm{pH} 7.4$, at $37^{\circ}$ and once at $4^{\circ}$. The binding of $125_{\text {I-labeled }}$ peptides was determined as previously described $(7,8)$. Insulin binding was carried out at $15^{\circ}$ for 3 hours and IGF-I and IGF-II binding was carried out at $15^{\circ}$ for 5 hours in the presence of approximately 0.2 to $0.4 \mathrm{ng} / \mathrm{ml}$ of 125 I-labeled peptide $(0.05$ 
$\mu \mathrm{Ci} / \mathrm{ml}$ ). Non-specific binding was determined in the presence of 5 $\mu \mathrm{g} / \mathrm{ml}$ IGF 1932 or $10 \mu \mathrm{g} / \mathrm{ml}$ of insulin.

AFFINITY CROSS-LINKING: Affinity cross-linking experiments were done as previously described $(8,9)$ with the following modifications. The concentration of 125 I-labeled peptide ranged from $5 \mathrm{ng} / \mathrm{ml}$ to $7.5 \mathrm{ng} / \mathrm{ml}$. After cross-linking with disuccinimidyl suberate, the cells were solubilized with $0.2 \mathrm{ml}$ of $80 \mathrm{mM}$ Tris $\mathrm{pH} 6.8$, containing $2 \%$ SDS, $10 \%$ glycerol and $0.01 \%$ bromphenyl blue in the absence or presence of $100 \mathrm{mM}$ dithiothreitol. The cells were collected by scraping with a rubber policeman and boiled for 3 minutes. Portions were subjected to electrophoresis on $5 \%$ or $6 \%$ acrylamide gels containing $0.1 \%$ SDS. Staining and autoradiography were performed as previously described (9). Molecular weight standards used were filamin $250 \mathrm{kDa}$, myosin $200 \mathrm{kDa}$, ß-galactosidase $116 \mathrm{kDa}$, and phosphorylase $\mathrm{B} 92 \mathrm{kDa}$.

\section{RESULTS AND DISCUSSION}

Hofmann and associates $(1,2)$ have recently reported that MDCK cells do not display insulin receptors as determined by immunoprecipitation studies. As shown in Table I, only a small amount of insulin binds to MDCK cells relative to IGF-I and IGF-II.

Table I

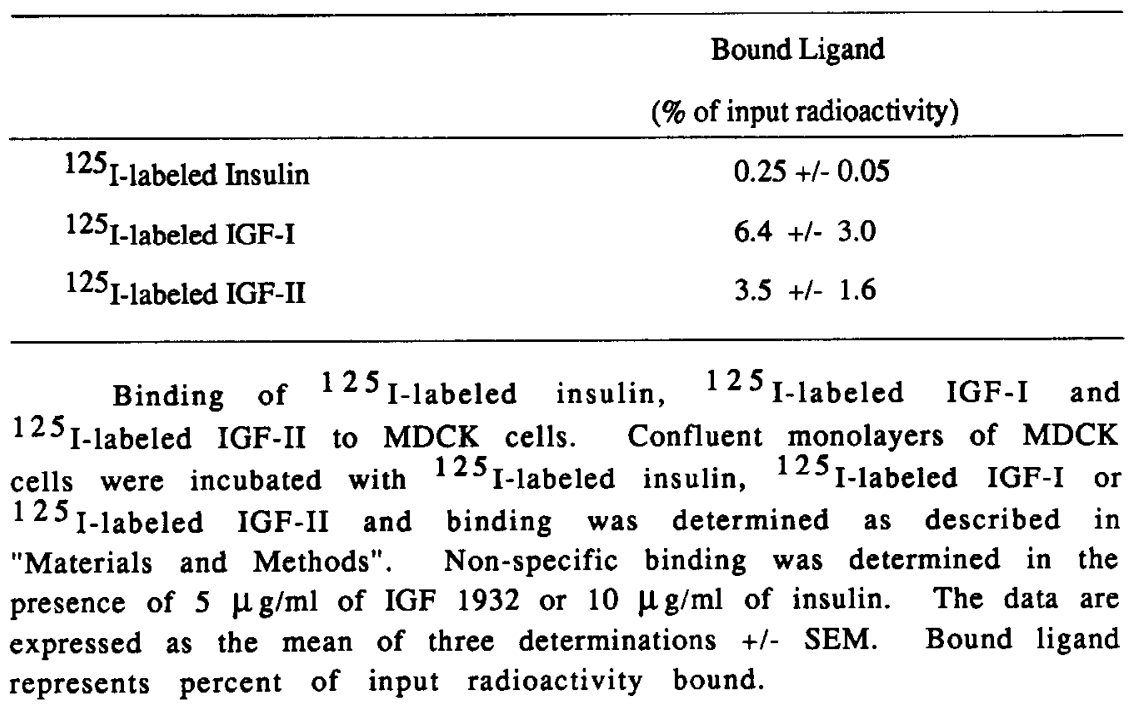


The amount of insulin binding is only $4 \%$ of the IGF-I binding and $7 \%$ of the IGF-II binding.

\section{Definition of IGF receptors in MDCK cells}

To determine which receptors bind the $125_{\text {I-labeled peptides, }}$ bound 125 I-labeled peptides were cross-linked to the cells with disuccinimidyl suberate and subjected to SDS-polyacrylamide gel electrophorsis under reducing and non-reducing conditions. Insulin and type I IGF receptors are reported to consist of two distinct subunits linked by disulfide bonds $(3,4)$. Under reducing conditions, the binding subunit (alpha subunit) migrates at $130 \mathrm{kDa}$ while under non-reducing conditions the receptor migrates at $>300 \mathrm{kDa}$. In contrast the type II IGF receptor consists of a single polypeptide chain migrating at $220 \mathrm{kDa}$ under non-reducing conditions and at $260 \mathrm{kDa}$ under reducing conditions.

As shown in Figure 1, $125_{\text {I-labeled IGF-I cross-links to a }>300}$ $\mathrm{kDa}$ protein in MDCK cells under non-reducing conditions and to a 130 $\mathrm{kDa}$ protein under reducing conditions. ${ }^{125}$ I-labeled IGF-II binds to a protein migrating at $220 \mathrm{kDa}$ under non-reducing conditions and to a $260 \mathrm{kDa}$ protein under reducing conditions. Formation of 125 I-labeled IGF-I and IGF-II : receptor complex is inhibited by 5 $\mu \mathrm{g} / \mathrm{ml}$ of IGF 1932. These data are consistent with the presence of a type I IGF receptor and a type II IGF receptor in MDCK cells. To indicate the position of the insulin receptor, 125 I-labeled insulin was cross-linked to $\mathrm{H}-35$ cells and subjected to eletrophoresis in parallel to 


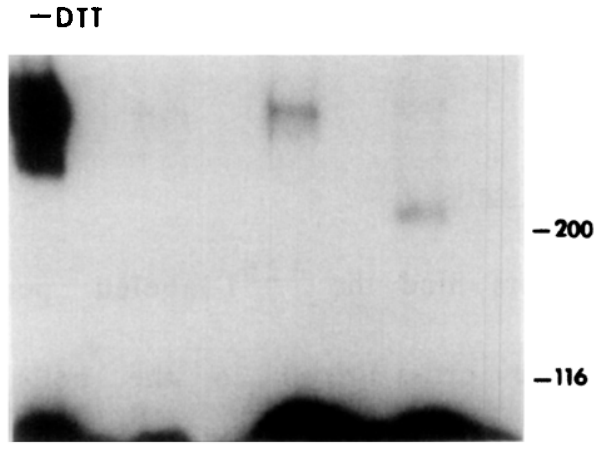

125,-LABEL INSULIN INSULIN IGF-I IGF-II UNLABELED -+-+-+-+ CELLS H-35 MDCK MDCK MDCK

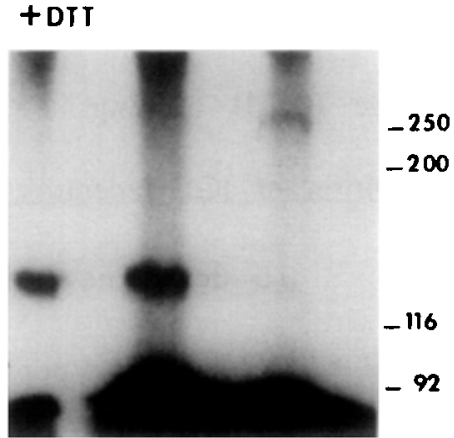

INSULIN IGF-I IGF-II $-+-+-+$ H-35 MOCK MDCK

Figure 1: Affinity cross-linking of $125_{\text {I-labeled insulin, } 125_{\text {I-1abeled }}}$ IGF-I and $125_{\text {I-labeled IGF-II. MDCK cell monolayers were incubated }}$

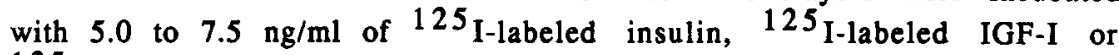
$125 \mathrm{I}$-labeled IGF-II in the presence of $5 \mu \mathrm{g} / \mathrm{ml}$ IGF 1932 or $10 \mu \mathrm{g} / \mathrm{ml}$ insulin; or without added peptide. Similarly, H-35 cells were incubated with ${ }^{125}$ I-labeled insulin with or without $10 \mu \mathrm{g} / \mathrm{ml}$ insulin. Affinity cross-linking of bound radioligand was as described in "Materials and Methods". Equivalent amounts of protein were subjected to eletrophoresis on a $5 \%$ acrylamide gel under non-reducing conditions or a $6 \%$ acrylamide gel under reducing conditions. Autoradiograms of the gels are shown. The position of molecular weight markers filamin $(250 \mathrm{kDa})$, myosin $(200 \mathrm{kDa})$, B-galactosidase $(116 \mathrm{kDa})$ and phosphorlyase $\mathrm{B}(92 \mathrm{kDa})$ is shown. Competition by unlabeled ligand refers to competition by the homologous ligand.

material from the MDCK cells. Under reducing conditions, 125 I-labeled insulin binds to a $130 \mathrm{kDa}$ protein in $\mathrm{H}-35$ cells

(Figure 1). Under non-reducing conditions, 125 I-labeled insulin cross-links to a protein migrating at $>300 \mathrm{kDa}$ protein in $\mathrm{H}-35$ cells. The formation of ${ }^{125}$ I-labeled insulin : receptor complex in H-35 cells

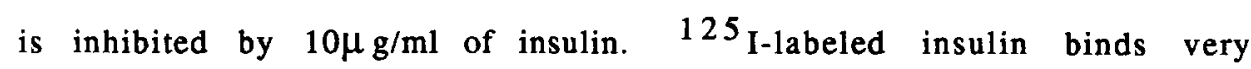
weakly to MDCK cells; however, since Hofmann and asssociates could not detect insulin receptors in these cells by immunoprecipitation 


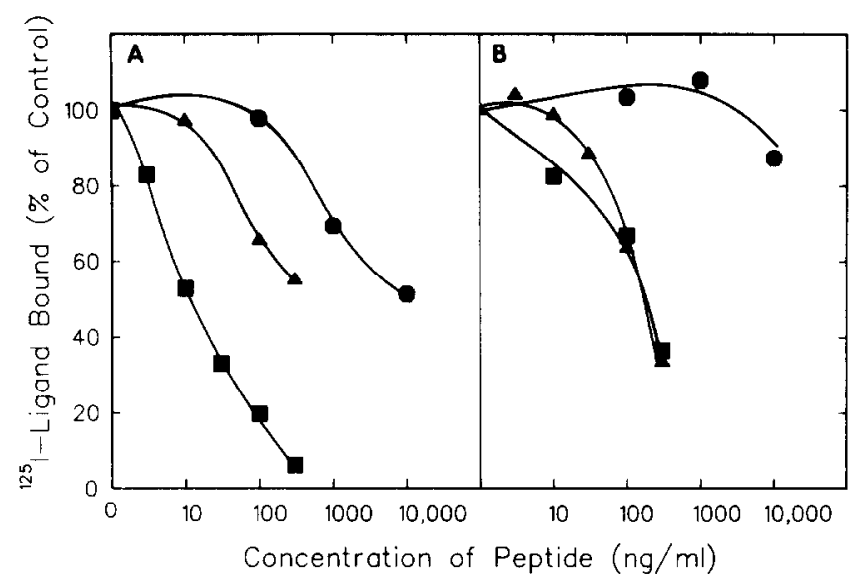

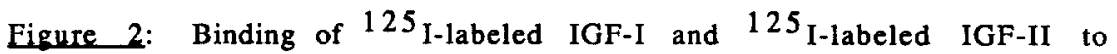
MDCK cells: competition by unlabeled insulin, IGF-I and IGF-II. The binding of 125 I-labeled IGF-I (Panel A) and $125_{\text {I-labeled IGF-II }}$ (Panel B) to monolayer cultures of MDCK cells was determined as described under "Materials and Methods" in the presence of increasing concentrations of unlabeled insulin ( $)$, IGF-I ( $\mathbf{a})$ or IGF-II ( $\boldsymbol{A}$ ). Corrections were made for non-specific binding in the presence of 5 $\mu \mathrm{g} / \mathrm{ml}$ of IGF 1932. Each point represents the mean of 4 culture dishes from two separate experiments. $100 \%$ of control binding represents $16.75+/-9.2 \mathrm{pg} / \mathrm{ml}$ for IGF-I and $11.4+/-5.9 \mathrm{pg} / \mathrm{ml}$ for IGF-II.

studies (2), this ${ }^{125}$ I-labeled insulin binding in MDCK cells most probably represents binding to a type I IGF receptor (see also Fig. 2).

Thus, MDCK cells display type I IGF and type II IGF receptors, but not insulin receptors.

Characterization of IGF receptors in MDCK cells

Type I and type II IGF receptors arc further characterized by the competition binding studies shown in Figure 2. Type I IGF receptors preferentially bind IGF-I > IGF-II > insulin and the type II IGF receptors preferentially bind IGF-II > IGF-I with virtually no affinity for insulin $(3,4,8)$. In MDCK cells, the concentration of IGF-I that half-maximally displaces

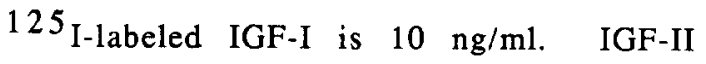


and insulin also displace labeled IGF-I but at much higher concentrations; half-maximal displacement is at $300 \mathrm{ng} / \mathrm{ml}$ and $8 \mu \mathrm{g} / \mathrm{ml}$ respectively. The concentration of IGF-I and IGF-II that half-maximally displaces 125 I-labeled IGF-II is $150 \mathrm{ng} / \mathrm{ml}$. Insulin

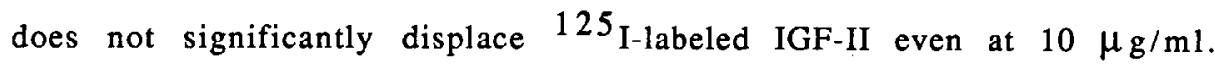

The affinity of binding and the number of binding sites per cell for the type I and type II IGF receptors was estimated by Scatchard analysis of the competition binding data. For the type I IGF receptor, the affinity of binding is $1.9+/-0.7 \mathrm{nM}$ with approximately 29,000 binding sites per cell. IGF-II binds to the type II IGF receptor with an affinity of $1.35+/-0.25 \mathrm{nM}$ with approximately 145,000 binding sites per cell. The affinity of binding and number of binding sites per cell are similar to those reported for the type I and type II IGF receptors in other cell systems (10-14). However, the competition binding data and affinity cross-linking data are consistent with $125_{\text {I-labeled IGF-II }}$ binding to both the type I IGF and the type II IGF receptors with approximately equal affinity, which may give an overestimation of the number of type II IGF receptors.

In cells containing both insulin and IGF receptors, it is often difficult to distinguish which receptor may be responsible for mediating a particular action due to the interaction of the peptides with the heterologous receptors. As MDCK cells display both type I IGF and type II IGF receptors, but not an insulin receptor, they 
provide a useful model in which to study the actions of the IGFs in the absence of an insulin receptor.

ACKNQWLEDGEMENTS: This work was supported by a research grant from the National Institutes of Health, AM 30055. NLK was supported by National Institutes of Health training grant, GM 07544. We thank Professor Rene Humble for providing IGFs. We also thank Dr. Cecilia Hofmann for providing MDCK cells and for helpful discussion.

\section{REFERENCES}

1. Hofmann, C.A., Lotan, R.M., Ku, W.W., and Oeltmann, T.N.

J. Biol. Chem. 258, 11774-11779.

2. Hofmann, C., Crettaz, M., Bruns, P., Hessel, P., and Hadawi, G. (1985) I. Cell. Biochem. 27, 401-414.

3. Rechler, M.M., Kasuga, M., Sasaki, N., DeVroede, M.A., Romanus, J.A., and Nissley, S.P. (1983) In: Insulin-like Growth Factors/ Somatomedins. (Spencer, E.M., ed.) pp. 459-490. Walter de Gruyter, New York.

4. Rechler, M.M., and Nissley, S.P. (1985) Ann. Rev. Physiol. 47, 425 - 442.

5. Fraker, P.J., and Speck, J.C. (1978) Biochem. Biophys. Res. Commun. 80, 849-857.

6. Froesch, E.R., Schmid, Chr., Schwander, J., and Zapf, J. (1985) Ann. Rev. Physiol. 47, 443-467.

7. Heaton, J.H., and Gelehrter, T.D. (1981) J. Biol. Chem. 256, $12257-12262$.

8. Heaton J.H., Krett, N.L., Alvarez, J.M., Gelehrter, T.D., Romanus, J.A., and Rechler, M.M. (1983) J. Biol. Chem. 259, 2396-2402.

9. Kasuga, M., Van Obberghen, E., Nissley, S.P., and Rechler, M.M. (1981) J. Biol. Chem. 256, 5305-5308.

10. Rosenfeld, R.G., and Dollar, L.A. (1982) J. Clin. Endocrinol. and Metab. 55, 434-440.

11. Sara, V.R., Hall, K., Misaki, M., Fryklund, L., Christensen, N., and Wetterberg, L. (1983) J. Clin. Invest. 71, 1084-1094.

12. Oppenheimer, C.L., Pessin, J.E., Massague, J., Gitomer, W., and Czech, M.P. (1983) J. Biol. Chem. 258, 4824-4830.

13. DeVroede, M.A., Romanus, J.A., Standaert, M.L., Pollet, R.J., Nissley, S.P., and Rechler, M.M. (1984) Endocrinology 114, 1917-1929.

14. Thorsson, A.V., Hintz, R.L., Enberg, G., and Hall, K. (1985) J. Clin. Endocr. Metab. 60,387-391. 